Mateusz Kępa

Uniwersytet Wrocławski

\title{
Polityka narodowościowa II Rzeczypospolitej wobec Łemków
}

DOI: $10.19195 / 1643-0328.20 .4$

Słowa kluczowe: polityka narodowościowa, Łemkowie, II Rzeczpospolita, asymilacja

\section{Wprowadzenie}

Na wstępie niniejszej pracy należałoby niewątpliwie przedstawić pochodzenie ludności łemkowskiej i samej nazwy „Łemko”. Polska historiografia zakłada, że wykształcenie się Łemkowszczyzny jako odrębnego obszaru etnograficznego nastąpiło podczas kolonizacji wołowskiej w XIV-XVI wieku' ${ }^{1}$. Kolonizacji tego terenu dokonali Rusini za czasów panowania Kazimierza Wielkiego, wędrując na północną stronę Karpat $^{2}$. Znawcy tematu uważają również, że protoplastami Łemków było plemię Białych Chorwatów zamieszkujących te ziemie już od $\mathrm{V}$ wieku ${ }^{3}$. W niniejszej pracy nazwa „Łemkowie” będzie rozumiana jako grupa etniczna, a nie naród, gdyż formalnie w literaturze naukowej nigdy nie uznano narodowości łemkowskiej.

Nazwa „Łemkowie” została spopularyzowana dopiero w pierwszej połowie XIX wie$\mathrm{ku}^{4}$, ludność ta zaczęła jej używać dopiero na przełomie XIX i XX wieku wymiennie ze starą nazwą „Rusini”. Dopiero okres po II wojnie światowej na trwałe przyjął owe nazewnictwo. Łemkowie, którzy w rzeczywistości wywodzą się od Rusinów Karpackich, zamieszkiwali południowo-wschodnie tereny Rzeczypospolitej Polskiej. W literaturze historiograficznej za teren przez nich zamieszkiwany uważa się linię północno-połu-

${ }^{1}$ J. Czajkowski, Dzieje osadnictwa historycznego na Podkarpaciu i jego odzwierciedlenie w grupach etnograficznych, [w:] idem, Łemkowie i historii i kulturze Karpat, Rzeszów 1992, s. 27-166; Zob. A. Fastnach, Osadnictwo Ziemi Sanockiej w latach 1340-1650, Wrocław 1962.

${ }^{2}$ B. Horbal, Działalność polityczna Łemków na Łemkowszczyźnie 1918-1921, Wrocław 1997, s. 16.

3 Ibidem, s. 17.

4 W literaturze poruszającej tematykę ludności Łemkowskiej przyjęło się uważać, że nazwa „Łemko” po raz pierwszy została użyta przez Josyfa Lewickyj w dziele Grammatik der ruthenischen oder kleinerussischen Sprache in Galizien, Przemyśl 1834. 
dniową łączącą Rymanów z Sanokiem oraz obszar od zachodniej strony rzeki Poprad, aż do pasma Wielkiego Działu leżącego na wschodzie ${ }^{5}$. Wart podkreślenia w kontekście tematyki niniejszej pracy jest fakt, że w okresie II Rzeczypospolitej Łemkowszczyznę zamieszkiwało około 150 tys. Łemków rozlokowanych w około $250 \mathrm{wsiach}^{6}$.

Na mocy ustaleń zawartych w traktacie wersalskim z 1919 roku oraz traktatu pokojowego z Austrią zawartego w Saint-Germain-en-Laye w tym samym roku Rada Ambasadorów zaaprobowała wschodnie granice, jakie miały być przyznane Rzeczypospolitej na mocy traktatu ryskiego z $1921 \mathrm{roku}^{7}$. Postanowienie to zostało entuzjastycznie przyjęte przez polskie władze, aczkolwiek wynikły również obawy, które dotyczyły możliwości upomnienia się narodu ukraińskiego o swoje utracone ziemie i wniesienia interpelacji do Ligi Narodów. Warto zauważyć, że polityka rządu przedsanacyjnego dzięki wprowadzeniu pewnych rozwiązań prawnych ukształtowała relacje polsko-ukraińskie aż do wybuchu II wojny światowej. Podstawowe założenia tych regulacji prawnych to przede wszystkim zapewnienie trwałości posiadania ziem przyznanych na mocy wspomnianych traktatów. Osiągnięcie tego celu miało nastąpić poprzez kolonizację wojskowąa ${ }^{8}$, wzrost znaczenia Kościoła rzymskokatolickiego na ziemiach wschodnich kraju oraz rozwój szkolnictwa w duchu polskim? 9

\section{Dwie koncepcje}

Kwestię ukraińską podjął ówczesny premier RP Władysław Sikorski, który skonkretyzował ją w swoim programie politycznym składającym się z dwóch dokumentów wydanych w marcu i kwietniu 1923 roku. Owe dokumenty, czyli odezwa do obywateli kresów wschodnich oraz tajne opracowanie w sprawie zaleceń polityki rządu na kresach ${ }^{10}$ zakładały normalizację i zrównoważenie stosunków polsko-ukraińskich poprzez zjednoczenie na stałe kresów z ojczystą krainą, co w efekcie miało doprowadzić do asymilacji narodu ukraińskiego ${ }^{11}$. Premier Sikorski dodatkowo postulował inicjatywę regionalizmu, która miała polegać na uwzględnieniu odmienności kulturowej i religijnej Ukraińców. Poprzez wynajdywanie określonych grup społecznych będących lojalnymi wobec władzy RP postulował utworzenie „ukraińskiej partii ugodowej”'12. Władysław Sikorski słusznie twierdził, że po zapadłej decyzji Rady Ambasadorów, środowiska ukraińskie będą próbowały dążyć, współmiernie do władz polskich, do osiągnięcia porozumienia

${ }^{5}$ B. Horbal, op. cit., s. 13-14.

6 Ibidem, s. 14.

7 Zob. R. Torzecki, Kwestia ukraińska w Polsce w latach 1923-1929, Kraków 1989, s. 20-31.

8 Zob. T. Böhm, Osadnictwo wojskowe na Kresach Wschodnich w II Rzeczypospolitej, „Dzieje Najnowsze" 1992, z. 1-2, s. 3-12.

9 J. Lewandowski, Konflikt polsko-ukraiński na tle konfliktów narodowych w Europie środkowo-wschodniej w XIX i XX w., „Warszawskie Zeszyty Ukrainoznawcze” 1994, z. 2, s. 84.

10 R. Torzecki, op. cit., s. 21.

11 Ibidem, s. 23.

12 Ibidem, s. 25. 
zapewniającego pewną stabilizację między obydwoma narodami. Wobec przedstawianych założeń doszło do zapoczątkowania kontaktów ze stronnictwami opowiadającymi się za rządami Moskwy ${ }^{13}$.

Proponowana przez premiera Sikorskiego droga polityki narodowościowej wobec ukraińskiej zaczęła tracić na znaczeniu w wyniku rozrastającego się wpływu stronnictw prawicowych w państwie. Już 25 stycznia 1924 roku minister spraw wewnętrznych Władysław Sołtan, kierujący tym resortem w rządzie Władysława Grabskiego, przedstawił program, który w zasadniczy sposób reformował założenia polityki wobec kwestii ukraińskiej przedstawionej przez Sikorskiego. Owe reformy miały na celu zwiększenie wpływu Rzeczypospolitej na działalność Kościoła greckokatolickiego, zwiększanie w szkolnictwie przedmiotów w języku polskim, osiedlenia ludności polskiej wzdłuż Zbrucza oraz zagłębia naftowego. Sołtan odwoływał się również do wcześniejszej idei Sikorskiego, a mianowicie utworzenia ugodowej grupy ukraińskiej oraz wyposażenia jej w dochodowe koncesje $\mathrm{e}^{14}$.

Szczególnie ważnym krokiem w kwestii regulacji prawnych terenów południowo-wschodnich RP były projekty tak zwanych ustaw kresowych zaproponowanych przez rząd Władysława Grabskiego. Owe ustawy miały dotyczyć języka państwowego i języków władz rządowych oraz samorządowych w aparatach administracyjnym, sądowym, prokuratorskim, notarialnym oraz organizacji edukacji. Działalność przygotowawcza rozpoczęła się już w kwietniu 1924 roku, a nad pracami czuwała tak zwana Komisja Czterech ${ }^{15}$. Wszystkie posiedzenia były utajnione, co budziło nerwowość i irytację u ludności ukraińskiej. W tym czasie często dochodziło do licznych protestów i wieców sprzeciwiających się tak prowadzonej polityce narodowościowej RP. Fala dezaprobaty wobec takich działań dotarła również do ziem zamieszkiwanych przez Łemków, w szczególności do Sanoka i Leska ${ }^{16}$.

Projekt ustaw opracowany przez Komisję Czterech został przedstawiony w sejmie, który je przyjął i uchwalił w lipcu 1924 roku. Podstawowe założenia jawiły się następująco: język polski, jako podstawowy język państwowy, języki mniejszości pełniły tylko funkcje pomocnicze, zmieniono nazwę język „ukraiński” i wprowadzono prawnie ustanowioną nazwę język „ruski”. Do całego projektu została wprowadzona tylko jedna poprawka przedstawiona przez Stanisława Thugutta, który postulował dodanie obok wyrażenia język „ruski”, słowa „rusiński”. Terminy te określały język, którym posługiwała się ludność ukraińska.

Warto zauważyć, że w tych ustawach ludność ukraińska została pozbawiona przymiotów własnej kultury, a wręcz własnej nazwy, która była używana od dziesięcioleci. Można zauważyć, że działalność prawodawcza rządu Grabskiego zmierzała do usunięcia „sprawy ukraińskiej” i nadania jej specyfiki „sprawy ruskiej”. Spełnienie tych intencji

13 R. Torzecki, op. cit., s. 81.

14 Zob. M. Papierzyńska-Turek, Sprawa ukraińska w II Rzeczypospolitej 1922-1926, Kraków 1979, s. $216-217$.

15 W skład komisji wchodzili: S. Grabski (ND), S. Thugutt (PSL „Wyzwolenie”), E. Straczewski (PSL „Piast”), H. Löwenherz (bezpartyjny).

16 M. Papierzyńska-Turek, op. cit., s. 221. 
oznaczałoby powrót do polskiej myśli politycznej z połowy XIX wieku, kiedy to często w Rusinach widziano Polaków, a język ruski był traktowany jak odmiana języka polskiego, pewien regionalny dialekt ${ }^{17}$. Można więc uznać, że cała działalność twórców ustaw miała na celu polonizację ludności ukraińskiej, ale również ludności białoruskiej oraz litewskiej ${ }^{18}$.

Stronnictwa prawicowe przedstawiły swój program polityczny, wedle którego miało dojść do asymilacji narodowej ludności ukraińskiej. Większość założeń kół prawicowych można odnaleźć w publikacjach Stanisława Grabskiego, który w ramach kwestii narodowościowych wsławił się cyklem artykułów „Kresy i narodowości” wydanym w 1930 roku na łamach „Lwowskiego Kuriera Porannego”. Dopominał się on o wzmożoną akcję osiedlania ludności polskiej na terenach między Przemyślem a Tarnopolem. W wyniku takiego zabiegu oczekiwał rozdzielenia jedności etnicznej Ukraińców ${ }^{19}$. Podobne postulaty wysuwał Jędrzej Giertych, który uważał, że „kwestia ukraińska” w ramach Rzeczypospolitej nie ma cech wartości narodowej, lecz stanowi koncepcję polityczną. Zbieżnie jak Władysław Sikorski, choć z odrębnej perspektywy, Giertych uważał, że dla interesów RP lepiej jest wspomagać ruch staroruski, który ma stanowić przeciwciężar wobec ukraińskiego ruchu narodowego ${ }^{20}$.

Po przewrocie majowym na pierwszy plan, dotyczący kwestii narodowościowych na ziemiach wschodnich RP, wysunęła się koncepcja asymilacji państwowej. Podczas zebrania Rady Ministrów w dniu 18 sierpnia 1926 roku Józef Piłsudski, który sprawował urząd ministra spraw wojskowych, zaznaczył, że należy dążyć do zmiany programu polityki narodowościowej RP, stopniowo przechodząc z koncepcji asymilacji narodowej do asymilacji państwowej ${ }^{21}$. Postulat ten został przedstawiony w artykule „Punkt wyjścia w sprawie ukraińskiej w Małopolsce Wschodniej” autorstwa Piotra Dunina-Borkowskiego. Ten były wojewoda lwowski przekonywał ludność ukraińską, że siła państwa zależy przede wszystkim od liczby lojalnych obywateli. Jako przykład podawał stosunek Austro-Węgier do Polski, które poprzez nadanie wolności kulturalnej Polakom, silnie połączyły ich z instytucją państwa ${ }^{22}$. Za podstawowe czynniki asymilacji państwowej Dunin-Borkowski uważał nieustanne podtrzymywanie entu-

17 J. Kozik, Między reakcja a rewolucją: studia $z$ dziejów ukraińskiego ruchu narodowego $w$ latach 1948-1949, Kraków 1979, s. 184; J. Moklak, Relacje między ukraińskim ruchem narodowym a moskalofilstwem w Galicji Wschodniej w latach 1866-1890, Kraków 1985, s. 24; S. Pijaj, Florian Ziemiałkowski a „kwestia ukraińska", [w:] Przez dwa stulecia, red. W. Frazik, Kraków 1993, s. 35-49.

18 M. Papierzyńska-Turek, op. cit., s. 233; P. Stawecki, Następcy Komendanta. Wojsko a polityka wewnętrzna II Rzeczypospolitej w latach 1935-1939, Warszawa 1969, s. 171.

19 T. Piotrkiewicz, Kwestia ukraińska w Polsce w koncepcjach Piłsudczyzny 1926-1930, Warszawa 1981, s. 128; Zob. S. Grabski, Kresy i narodowości, „Lwowski Kurier Poranny” 1930.

20 J. Giertych, O programie polityki kresowej, Warszawa 1932, s. 31.

21 Cz. Madajaczyk, Dokumenty w sprawie polityki narodowościowej władz polskich na Kresach Wschodnich, „Dzieje Najnowsze” 1972, z. 1-2, s. 138.

22 P. Dunin-Borkowski, Punkt wyjścia w sprawie ukrainskiej w Małopolsce Wschodniej, „Droga” 1929, nr 6, s. 569. 
zjazmu i satysfakcji wśród ludności ukraińskiej, litewskiej czy białoruskiej z warunków świadczonych przez państwo ${ }^{23}$.

Osiągnięcie zamierzonego celu było możliwe poprzez realizację działań o charakterze instytucjonalnym. Przede wszystkim chodziło o ukształtowanie określonej jednostki terytorialnej sformowanej z terenów południowo-wschodnich oraz części obszaru województwa lubelskiego. Ludność ukraińska zamieszkująca te tereny miałaby otrzymać autonomię $\mathrm{w}$ zakresie kultury i religii. Współpraca polityczna z kołami ukraińskimi odbywałaby się w ramach relacji między grupą ugodową znajdującą się w Ukraińskim Zjednoczeniu Narodowo-Demokratycznym (UNDO) i pewnymi zrzeszeniami staroruskimi $^{24}$. Piotr Dunin-Borkowski nie podjął w swojej publikacji kwestii miejsca narodu Łemków w II RP. Mogło to wynikać z faktu, że temat ten nie był poruszany na arenie politycznej. Niewątpliwym jest fakt, że jako wojewoda lubelski musiał się stykać z problematyką narodowościową Łemków, którzy zamieszkiwali powiaty sanocki i krościeński ${ }^{25}$, znajdujące się pod zarządem Dunina-Borkowskiego. Wobec stronnictw popierających Moskwę nie planował wspólnej działalności politycznej, gdyż, jak twierdził, jest to śladowy odsetek ludności ukraińskiej, bez znaczenia politycznego ${ }^{26}$. Zasady asymilacji państwowej przedstawione zostały również w broszurze O konstruktywna politykę na Rusi Czerwonej autorstwa Stanisława Łosia ${ }^{27}$.

Program asymilacji państwowej był również przedstawiany na początku lat 30. ubiegłego wieku. Jako jednego z głównych propagatorów tej koncepcji można wymienić bez wątpienia postać Tadeusza Hołówki, który na początku swojej kariery był powiązany z ministerstwem spraw wewnętrznych, natomiast w latach późniejszych aktywnie działał przy polskim ministerstwie spraw zagranicznych. Na przełomie lipca i sierpnia 1930 roku ukazały się w „Gazecie Polskiej” artykuły autorstwa Hołówki, które nosiły zbiorowy tytuł „Kresy”. W owych publikacjach polemizował on z poglądami Stanisława Grabskiego zawartymi we wspomnianym cyklu artykułów z tegoż samego roku pt. „Kresy i narodowości”. Za jedno z podstawowych założeń myśli politycznej Tadeusza Hołówki należy przyjąć koncepcję włączenia ludności ukraińskiej do polskiej państwowości, scalenia tych dwóch kwestii w jedną spójną całość. Warto wspomnieć, że w literaturze pojawiają się poglądy, jakoby to Hołówko miał sprawować zarząd nad pewną autonomiczną jednostką, w skład której miały wchodzić tereny województw południowo-wschodnich. W ramach tego zarządu zamierzał on realizować nie do końca określoną politykę narodowościową wobec ludności Ukraińskiej ${ }^{28}$.

23 T. Piotrkiewicz, op. cit., s. 130.

24 Ibidem, s. 123.

25 Zob. A. Chojnowski, Koncepcje polityki narodowościowej rządów polskich w 1921-1931, Wrocław 1979, s. 102-106.

26 P. Dunin-Borkowski, op. cit., s. 572; T. Piotrkiewicz, op. cit., s. 123.

27 Zob. także A. Bocheński, S. Łoś, W. Bączkowski, Problem polsko-ukraiński w ziemi czerwińskiej, Warszawa 1938.

28 T. Piotrkiewicz, op. cit., s. 121., Zob. I. Werschler, Z dziejów obozu belwederskiego. Tadeusz Hołówko, życie i działalność, Warszawa 1984, s. 298-302. 


\section{Kwestia łemkowska}

Skupiając się w tej części pracy na kwestii łemkowskiej w polityce narodowościowej II Rzeczypospolitej, należy podkreślić, że wywiązała się ona niejako pochodną „sprawy ukraińskiej" i stanowiła jej określoną część. Kwestia łemkowska była rozstrzygana na tle szerszych działań rządu polskiego skierowanego wobec ludności niepolskiej w celu zapewnienia ugodowych relacji różnych grup etnicznych i narodowościowych występujących ówcześnie na terenach $\mathrm{RP}^{29}$. Warto zauważyć, że istotny wpływ na działania rządu wobec mniejszości miał bez wątpienia kryzys gospodarczy i polityczny, z którym od początku lat 30. borykała się Polska. Załamanie się rynku rolnego, a w konsekwencji dalszy jego upadek, zwiększające się wydatki przy relatywnie niskich zarobkach musiały doprowadzić do głodu i ubóstwa, co sprzyjało wytworzeniu się atmosfery buntu i nienawiści. Wzmożona liczba protestów i manifestacji wobec państwa polskiego przyczyniła się do akcji represyjnych ze strony rządu w Warszawie wobec mniejszości na terenach wschodnich. Znaczącym faktem dotyczącym polityki RP wobec ludności łemkowskiej było stanowisko Kościołów katolickiego i greckokatolickiego wobec mniejszości narodowych. Początkowo zarówno jedno, jak i drugie wyznanie starało się wspierać mniejszości, w szczególności na terenach Galicji Wschodniej. Do początku lat 30. XX wieku ludność wyznania rzymskokatolickiego i greckokatolickiego żyła w ogólnej symbiozie, pomijając kilka incydentów na tle religijnym. Dopiero w 1930 roku po akcjach sabotażowych i terrorystycznych ze strony Organizacji Ukraińskich Nacjonalistów (OUN) ${ }^{30}$ pod przywództwem Jewhena Konowalca ${ }^{31}$, rząd polski przystąpił do akcji pacyfikacyjnej ${ }^{32}$ wobec mniejszości ukraińskiej, a w tym i łemkowskiej. Zarówno hierarchowie katoliccy, jak i greckokatoliccy potępili działalność OUN, choć duchowieństwo obrządku wschodniego również w ostrych słowach wypowiedziało się w sprawie agresywnej represji ze strony polskiej ${ }^{33}$. Akcja pacyfikacyjna, która miała przynieść pokój między narodami, spowodowała jedynie pogorszenie stosunków polsko-ukraińskich ${ }^{34}$. Kapłani obu ob-

29 J. Moklak, Łemkowszczyzna w Drugiej Rzeczypospolitej. Zagadnienia polityczne $i$ wyznaniowe, Kraków 1997, s. 154.

30 J. Hrycak, Historia Ukrainy 1772-1999. Narodziny nowoczesnego narodu, Lublin 2000, s. 198.

31 Jewhen Konowalec (1891-1938) — współtwórca i dowódca korpusu Strzelców Siczowych, pułkownik armii Ukraińskiej Republiki Ludowej oraz Ukraińskiej Armii Halickiej, ukraiński działacz nacjonalistyczny oraz współtwórca Ukraińskiej Organizacji Wojskowej, przywódca Organizacji Ukraińskich Nacjonalistów.

32 W opinii R. Potockiego: „Władze państwowe miały prawo do zwalczania wszelkiego rodzaju działalności secesjonistycznej czy terroru politycznego, lecz w drugiej połowie dekady notorycznie myliły ukraiński nacjonalizm z aspiracjami narodowymi tej społeczności. W 1935 roku zbyt łatwo zmarnowano szansę pozyskania dla polskiej państwowości przynajmniej części Ukraińców, w zamian za pewne prawa społeczno-ekonomiczne. W tej sytuacji zamiast zachęcać skutecznie zraziły do siebie tę grupę narodową. Zamiast niwelować konflikt etniczny, niejednokrotnie potęgowały go, poprzez nadmierną represyjność i odpowiedzialność zbiorową," zob. R. Potocki, Polityka państwa polskiego wobec zagadnienia ukraińskiego w latach 1930-1939, Lublin 2003, s. 227.

33 J. Hrycak, op. cit., s. 198-203.

34 S. Stępień, Nowa unia kościelna. Obrządek bizantyjsko-słowiański, [w:] Polska-Ukraina 1000 lat sasiedztwa, t. II, Studia z dziejów chrześcijaństwa. Na pograniczu kulturowym i etnicznym, red. S. Stępień, 
rządków, łacińskiego i wschodniego, zauważyli, że działania polityczne z jednej i drugiej strony zaogniają stosunki między oboma narodami, które przecież wcześniej potrafiły żyć w zgodzie, chociaż nie było to dla nich łatwe ${ }^{35}$.

W takim to właśnie okresie zaczęto podejmować kwestię ludności łemkowskiej w Rzeczypospolitej. Program polityki narodowościowej wobec Łemków został stworzony na podstawie wieloaspektowego badania na tle zarówno politycznym, społecznym, historycznym, kulturowym i psychologicznym. Bez wątpienia największy wkład w owe badania miał Władysław Wielhorski, który był specjalnym urzędnikiem działającym przy Prezydium Rady Ministrów. Całokształt badań przeprowadzonych przez Wielhorskiego został ujęty w maszynopisie z listopada 1933 roku pt. „Łemkowszczyzna”. Dokument ten kompleksowo przedstawił życie społeczne i kulturalne ludności łemkowskiej oraz opisał jej mentalność oraz aspekty psychologiczno-religijne. Na samym początku swojej pracy badawczej Wielhorski postanowił określić zasięg geograficzny terenów, na których żyła ludność łemkowska. Jako centralne skupiska Łemków określił on takie miejscowości, jak: Krynica, Lesko, Muszyna, Sanok, Jasło czy Gorlice. Ponadto, badając strukturę społeczną, Wielhorski zauważył, że większość tej społeczności to ludność chłopska o bardzo określonej mentalności, a tylko nielicznych z nich można zaklasyfikować do warstwy inteligencji, którą tworzyli przede wszystkim przedstawiciele wolnych zawodów zamieszkujących powyższe miasta. Przechodząc do mentalności ludności łemkowskiej, Wielhorski zauważył, że ta grupa etniczna cechuje się swoistymi zasadami, które są jasno zhierarchizowane $\mathrm{w}$ ich społeczeństwie ${ }^{36}$. Wartością nadrzędną jest przede wszystkim zapewnienie podstawowych warunków zabezpieczających byt, następnie bardzo istotnym czynnikiem psychologii Łemków jest zachowanie pewnej odrębności kulturowej wobec reszty społeczeństwa, co przejawia się w gloryfikowaniu i pielęgnowaniu swoistych tradycji czy wierzeń religijnych ${ }^{37}$. Łemkowie w opinii Wielhorskiego to ludność prymitywna, grupa chłopstwa umiejąca silnie walczyć o własną identyfikację etniczną, historyczną czy kulturową.

Na podstawie analizy badacz ów zauważył, że Łemkowie zamieszkujący określone zwarte tereny żyją w pewnej enklawie i dlatego trudno określić ich stosunek wobec Polaków i Rzeczypospolitej. Uważał on, że ludność łemkowska tworzy zamknięte społeczeństwo, a w kontaktach z ludnością polską i władzami nie wykazuje ani wrogości, ani sympatii. Jest to stosunek neutralny, bez emocji, chociaż Łemkowie wykazują tendencje do lojalności wobec państwa polskiego, jeśli agitacja stronnictw ukraińskich nie osłabia ich w tym przekonaniu ${ }^{38}$.

W procesie zbierania danych na temat Łemkowszczyzny Wielhorski dostrzegł silną więź emocjonalną łączącą ten lud z rejonami Europy Wschodniej i jej dziedzictwem. Można stwierdzić, że jest to grupa ludzi silnie związana z terenami wschodniej Sło-

Przemyśl 1994, s. 141-179; F. Rzemianiuk, Kościół katolicki obrządku bizantyjsko-słowiańskiego, Neounia, Lublin 1999, s. 53-98.

\footnotetext{
${ }^{35}$ M. Kępa, Kościót greckokatolicki w diecezji przemyskiej w II Rzeczypospolitej, Gdańsk 2014, nr 7, s. 142.

36 W. Wielhorski, Łemkowszczyzna, b.m.w. 1933, s. 6.

37 Ibidem.

38 Ibidem, s. 10.
} 
wiańszczyzny, co wynika z tradycji kulturowych formowanych już od okresu Rusi Kijowskiej ${ }^{39}$. Wart zauważenia jest również fakt, że ludność łemkowska w XX wieku bardzo łatwo poddawała się różnym koncepcjom politycznym docierającym na ich tereny, a w szczególności moskalofilstwu oraz wszelakim ruchom staroruskim ${ }^{40}$.

Należy podkreślić, że ogół zachowań społecznych i kulturalnych ludności łemkowskiej cechuje swoisty konserwatyzm związany z ich odrębnością etniczną i kulturową. Zważając na to Wielhorski skupił się w swojej pracy badawczej na tendencjach, które wykazuje ta grupa etniczna wobec działalności politycznej. Zauważył on, że to ów skromny odsetek inteligencji ludności łemkowskiej jest odpowiedzialny za kreowanie ich swoistej myśli politycznej. Przyglądając się tej określonej klasie społecznej, a w szczególności czołowym przedstawicielom łemkowskiego ruchu secesjonistycznego stwierdził, że cechują się oni dużą dozą racjonalności i trzeźwości myślenia wobec kwestii politycznych dotyczących terenów przez nich zamieszkiwanych. Łemkowscy separatyści zdawali sobie sprawę z tego, że nawet gdyby doszło to powstania państwa ukraińskiego postulowanego przez stronników ukraińskiego ruchu narodowego, to Łemkowszczyzna i tak na zawsze pozostanie w granicach Rzeczypospolitej, gdyż jest to uwarunkowane od jej geograficznego położenia na terenach stricte polskich ${ }^{41}$. Materiał badawczy zebrany i przeanalizowany przez Wielhorskiego pozwolił na określenie podstawowych wytycznych dla rządu polskiego w ramach kwestii łemkowskiej. Założenia przez niego poczynione zostały podzielone na kwestie dotyczące szkolnictwa i gospodarki. W ramach oświaty szczególnie istotnym czynnikiem była selekcja kardy nauczycielskiej, która miała pochodzić ze środowiska łemkowskiego lub polskiego, zaznajomionego z Łemkami. Kategorycznie wykluczeni byli nauczyciele pochodzenia ukraińskiego oraz wszelka inteligencja przybywająca z byłych terenów Galicji Wschodniej ${ }^{42}$. Aby zapewnić skuteczną edukację ludności łemkowskiej, postulowano stworzenie odmiennego seminarium nauczycielskiego dla Łemków lub powołania specjalistycznej jednostki nauczającej dialektu łemkowskiego przy seminarium w Nowym Sączu ${ }^{43}$. Miało się to przyczynić do powstania wykwalifikowanej kardy nauczycielskiej, wykładającej w dialekcie łemkowskim na terenach Łemkowszczyzny. Przede wszystkim podstawowym założeniem było odciągnięcie młodzieży łemkowskiej od szkół prowadzonych przez ukraińskich nauczycieli, zwolenników ukraińskiego ruchu narodowego. W ramach działalności pozaszkolnej proponowano stworzenie pisma dla ludu łemkowskiego $\mathrm{z}$ wyszczególnionym podziałem na literaturę, politykę i gospodarkę, które miało kształtować właściwy proces myślenia politycznego w społeczeństwie łemkowskim ${ }^{44}$.

W kwestii spraw gospodarczych Wielhorski postulował konieczność pomocy Łemkom $\mathrm{w}$ wyjściu z marazmu gospodarczego i zapewnienia lepszych i przede wszystkim godnych warunków życia. Sprawą oczywistą był rozwój infrastruktury drogowej na te-

\footnotetext{
${ }^{39}$ J. Moklak, op. cit., s. 155.

40 W. Wielhorski, op. cit., s. 11.

41 Ibidem, s. 12.

42 Ibidem.

43 Ibidem, s. 16.

44 J. Moklak, op. cit., s. 156.
} 
renach Łemkowszczyzny oraz skupienie się na przemyśle leśnym oraz rolnym. Zaproponował on specjalistyczną opiekę dla łemkowskich rolników, co miało doprowadzić do wzmocnienia świadomości państwowej Łemków i zdobycia ich lojalności. Zarówno w sprawach edukacji, jak i w gospodarce podstawowym założeniem było odciągnięcie ludności łemkowskiej od ukraińskich działaczy, w tym przypadku od ukraińskich spółdzielni świadczących usługi handlowo-kredytowe ${ }^{45}$.

Kolejnym krokiem Wielhorskiego, który miał prowadzić do asymilacji państwowej ludności łemkowskiej była reforma administracyjna mająca na celu włączenie powiatów krośnieńskiego i sanockiego do województwa krakowskiego. Ponadto postulował wytyczenie nowych granic powiatu sanockiego poprzez dołączenie do jego obszaru administracyjnego części terenów powiatu leskiego. Takie zabiegi miały prowadzić do skupienia w jednym obszarze administracyjnym wszystkich Łemków ${ }^{46}$.

Kilka miesięcy po sformułowaniu podstawowych założeń wobec kwestii łemkowskiej zaczęły się tworzyć określone struktury organizacyjne, które miały się przyczynić do realizacji owej sprawy. Już w marcu 1934 roku pierwsze działania rozpoczął Komitet do Spraw Narodowościowych działających przy Prezydium Rady Ministrów. Warto w tym miejscu wspomnieć, że pierwszym dyrektorem owego Komitetu został Władysław Wielhorski, doceniony za wkład pracy w badaniach nad Łemkowszczyzną. Na pierwszym posiedzeniu Komitetu, które odbyło się 2 marca, przedstawiono podstawowe zalecenia polityki narodowościowej oraz utworzono Komisję Naukowych Badań Ziem Wschodnich. Na następnym spotkaniu, które odbyło się 6 dni po inauguracyjnym posiedzeniu, ustalono konkretne założenia polityki władz polskich wobec ludności łemkowskiej ${ }^{47}$. W ramach kolejnych posiedzeń powołano Komisję do Spraw Prawosławia oraz Komitet do Spraw Polesia ${ }^{48}$.

Znaczące przemiany w strukturach i działalności Komitetu do Spraw Narodowościowych miały miejsce 19 marca 1935 roku za sprawą premiera Mariana Zyndram-Kościałowskiego. Zatwierdzona wówczas uchwała skonkretyzowała zadania oraz skład kadrowy Komitetu. Problematykę działalności Komitetu ujęto w czterech odrębnych blokach tematycznych. Było to, po pierwsze, stworzenie ogólnych dyrektyw polityki narodowościowej; po drugie, analiza badawcza oraz kompletowanie wszelakich materiałów związanych z kwestiami narodowościowymi; po trzecie, harmonizacja działalności gospodarczej z wytycznymi polityki narodowościowej oraz, po czwarte, aktywizacja inicjatywy społecznej afirmującej politykę władz polskich ${ }^{49}$.

Skład strukturalny Komitetu do Spraw Narodowościowych po kolejnych reformach ostatecznie przedstawiał się następująco. Na czele, jako przewodniczący, stał Prezes Rady Ministrów, jego zastępcą i de facto wiceprzewodniczącym był minister do spraw wewnętrznych, dalej znajdowali się ministrowie poszczególnych resortów: spraw wojskowych, rolnictwa i robót publicznych, spraw zagranicznych, wyznań religijnych

\footnotetext{
45 Ibidem.

46 W. Wielhorski, op. cit., s. 17.

47 J. Moklak, op. cit., s. 157.

48 Ibidem.

49 Ibidem.
} 
i oświecenia publicznego lub wyznaczani przezeń stali przedstawiciele. Sporządzona uchwała dopuszczała, jako członków, wybitnych znawców kwestii narodowościowych, którzy często byli powoływani przez przewodniczącego do różnego rodzaju konsultacji i rozstrzygnięć. Na mocy tej samej ustawy zostało ustanowione Biuro Polityki Narodowościowej mające funkcjonować przy Prezydium Rady Ministrów.

W strukturach Komitetu do Spraw Narodowościowych powołano specjalny Komitet do Spraw Łemkowszczyzny, który został obsadzony reprezentantami ministerstw spraw wewnętrznych, wojskowych oraz przedstawicielami kuratoriów lwowskiego i krakowskiego. W ramach owego Komitetu utworzono Podkomitet, który pełnił funkcję wykonawczą. Składał się on ze starostów powiatów oraz inspektorów obwodów szkolnych leżących na administracyjnych terenach Łemkowszczyzny. Dodatkowo w skład wchodzili wicewojewoda i kurator $\mathrm{z}$ okręgu krakowskiego, przedstawiciele resortu wojskowego wraz z generalnym kierownikiem Inspektoratu Straży Granicznej oraz członkowie Dowództwa Okręgu Korpusu nr V i X stacjonujący odpowiednio w Krakowie i Przemyślu ${ }^{50}$.

Wizytator do spraw szkolnictwa mniejszości narodowych, Ludwig Ręgorowicz, uważał, że zakres terytorialny Komitetu oraz Podkomitetu do Spraw Łemkowszczyzny winien być kompatybilny z terenami Apostolskiej Administracji Łemkowszczyzny, a więc obejmować dodatkowo również powiat brzozowski ${ }^{51}$. Ponadto, domagał się powołania do Komitetu przedstawiciela resortu wyznań religijnych i oświecenia publicznego, którym w efekcie został on sam ${ }^{52}$.

Istotna rola w kreowaniu polityki narodowościowej II Rzeczypospolitej przypadła Komisji Naukowych Badań Ziem Wschodnich, w skład której wchodziły regionalne koła naukowe. Sekcja dotycząca Łemkowszczyzny została powołana do życia w 1934 roku, a kierownictwo nad nią sprawował profesor Jerzy Smoleński ${ }^{53}$. W skład owej komisji wchodziło wielu wybitnych znawców nauk prawnych, społecznych oraz przyrodniczych. Poruszana tematyka badawcza oscylowała wokół zagadnień z demografii, fizjografii, socjologii, historii oraz etnografii. Profesor Smoleński szczególną uwagę poświęcał kwestii ruchu Łemków w aspektach demograficzno-narodowościowych ${ }^{54}$. Wszelakie prace terenowe prowadzone były pod patronatem Uniwersytetu Jagiellońskiego oraz Polskiej Akademii Umiejętności ${ }^{55}$. W powyższą działalność została zwerbowana młodzież z gimnazjum w Jaśle ${ }^{56}$. Sumiennie i autentycznie przeprowadzone badania pozwoliły formułować celne opinie na temat charakteru politycznego Łemków.

Warto zauważyć, że lata 1934-1935 charakteryzowały się kształtowaniem polityki narodowościowej wobec kwestii ukraińskiej, w ramach której problematyka kwestii

50 Ibidem, s. 158.

${ }^{51}$ L. Ręgorowicz, Materiały do dziejów wychowania. Zagadnienia łemkowskie w Polsce, Kraków 1934, s. $17-18$.

52 Zob. A. Brożek, Ręgrowicz Ludwik Walenty, „Polski Słownik Biograficzny”, t. XXXI, Wrocław 1988-1989, s. 246.

53 J. Moklak, op. cit., s. 158.

54 J. Smoleński, Łemkowie i Łemkowszczyzna, „Wierchy”, t. XIII, Kraków 1935, s. 57-58.

55 J. Moklak, op. cit., s. 158.

56 Ibidem. 
łemkowskiej była równocześnie traktowana jako sprawa odrębna. Wkrótce okazało się, że wcześniej sprzeczne ze sobą koncepcje asymilacji narodowej i państwowej zostały zsyntezowane w jeden spójny program przedstawiony 2 stycznia 1936 roku podczas zgromadzenia Komitetu do Spraw Narodowościowych przez premiera Zyndrama-Kościałowskiego.

Głównym założeniem owego programu było stworzenie stronnictwa ukraińskiego lojalnego wobec władz polskich i działającego na rzecz polonizacji ludności ukraińskiej na obszarach południowo-wschodnich. Warto wspomnieć, że postulowany ruch ukraiński miał dotyczyć tylko terenów zamieszkiwanych przez Ukraińców, poza sferą działań zostały obszary „czysto” polskie, w tym także Łemkowszczyzna. I tak w wyniku podjętych działań ludność ukraińska zamieszkująca powiaty polskie miała przejść proces asymilacji narodowej, natomiast na pozostałych terenach miał się dokonać proces asymilacji państwowej poprzez popieranie stronnictw ukraińskich o profilu polonofilskim ${ }^{57}$. Podstawą tych działań według Kościałkowskiego miało być całościowe równouprawnienie ludności ukraińskiej z ludnością polską.

Przedstawiony przez premiera program natrafił na trudną sytuację polityczną, związaną ze śmiercią marszałka Józefa Piłsudskiego, w wyniku której doszło do tak zwanej dekompozycji obozu sanacyjnego. Liczne stanowiska państwowe zajmowali przedstawiciele stanu wojskowego. Szczególną pozycją odznaczał się z pewnością Edward Rydz-Śmigły, który w porozumieniu z ówczesnym prezydentem Ignacym Mościckim powołali do życia gabinet Felicjana Sławoja-Składkowskiego ${ }^{58}$. Część oficerów uważała, że ze względu na trudną sytuację geopolityczną, w której znajdowała się wówczas Rzeczpospolita, należy dążyć do ustabilizowania wewnętrznej sytuacji w kraju, a w szczególności na terenach przygranicznych. Pozyskanie lojalności ludności z terenów Kresów Wschodnich było niejako zapewnieniem ochrony przed ewentualną inwazją ze wschodu. Istotna była też dlatego kwestia polityki narodowościowej wobec ludności ukraińskiej i białoruskiej oraz zjednanie sobie ich przychylności oraz lojalności wobec $\mathrm{RP}^{59}$.

W tym miejscu warto wspomnieć postać ministra do spraw wojskowych, Tadeusza Kasprzyckiego, jednego z zasadniczych kreatorów polityki Wojska Polskiego ${ }^{60}$. Uważał on, że kwestie polityczne winny być ściśle powiązane ze sprawami narodowościowymi i przede wszystkim wyznaniowymi. Postulował poddanie wszelakich mniejszości, w szczególności słowiańskich, pod proces asymilacji wyznaniowej i kulturowej w duchu propolskim i propaństwowym ${ }^{61}$.

57 J. Moklak, op. cit., s. 159.

58 H. Jędruszczak, T. Jędruszczak, Ostatnie lata Drugiej Rzeczypospolitej, 1935-1939, Warszawa 1970, s. $58-62$.

59 T. Prus-Faszczewski, Małopolska Wschodnia a zagadnienia obronności państwa, Warszawa 1939, s. $27-28$.

60 R. Torzecki, Polacy i Ukraińcy. Sprawa Ukraińska w czasie II wojny światowej na terenie II Rzeczypospolitej, Warszawa 1993, s. 13.

61 P. Stawecki, op. cit., s. 171-172; W. Paruch, Mniejszości narodowe myśli politycznej obozu piłsudczykowskiego (1935-1939), [w:] Polityka narodowościowa państw Europy środkowowschodniej, red. W. Paruch, Lublin 1993, s. 93. 
W owym czasie szczególnie dużo uwagi poświęcano terenom byłej Galicji Wschodniej. Wynikało to przede wszystkim ze znaczenia militarnego oraz gospodarczego owych obszarów. Były one bogate w przydatne surówce, na przykład ropę naftową czy sól potasową. Aby pokonać ewentualne problemy związane z mobilizacją wojskową, już od początku lat 30. zaczęto prowadzić akcje aktywizacji „szlachty zagrodowej ${ }^{62}$.

\section{Podsumowanie}

Rok 1939 od samego początku cechował się wyraźnym nasileniem działań rządu polskiego w kwestiach narodowościowych. Planowaną polonizacją ludności z terenów południowo-wschodnich opierano na granicach politycznych wytyczonych przez sztaby wojskowe ${ }^{63}$. Wzmożono asymilację narodową o kolejne części ziem wschodnich (województwa tarnopolskie i stanisławowskie) oraz nasilono działalność propolską na Lubelszczyźnie i Wołyniu ${ }^{64}$. Należy zauważyć, że już od czerwca 1938 roku rozpoczęto proces ograniczania działalności kulturalno-politycznej starorusinów łemkowskich poprzez likwidację czasopisma „Łemko”65. Mimo, że Łemkowszczyzna znajdowała się na marginesie spraw kresowych, to sprawy narodowościowe odgrywały szczególną rolą, co było widoczne w zmaganiach poszczególnych stronnictw o wpływy wśród ludności Łemkowskiej $^{66}$. W literaturze historycznej polityka narodowościowa prowadzona wespół z polityką wojskową jest często przedstawiana jako interes obronny Polski oparty na założeniach i metodach ideologii nacjonalistycznej ${ }^{67}$.

Okres przed rozpoczęciem II wojny światowej w polityce narodowościowej wobec ludności ukraińskiej jawił się jako proces „pacyfikacji” środowisk ukraińskich ${ }^{68}$. Koncepcje asymilacji państwowej i narodowej nie zdały egzaminu, a w wyniku przewartościowania, którym bez wątpienia był program wzmacniania „polskości” na terenach południowo-wschodnich mający na celu interes obronny RP, osiągnięto rezultaty niewspółmierne wobec pierwotnych założeń obozu rządzącego.

62 W. Paruch, op. cit., s. 99-100; Zob. R. Horoszkiewicz, Szlachta zagrodowa na ziemiach wschodnich, Warszawa 1936.

63 T.A. Olszański, Historia Ukrainy XX w., Warszawa 1994, s. 151-153; A. Chojnowski, op. cit., s. 236-239; J.M. Majchrowski, Silni-zwarci-gotowi. Myśl polityczna Obozu Zjednoczenia Narodowego, Warszawa 1985, s. 119.

64 J. Moklak, op. cit., s. 161.

65 Ibidem, s. 162.

66 J. Tomaszewski, Stosunki narodowościowe w Drugiej Rzeczypospolitej, [w:] Polska Niepodległa 1918-1939, red. J. Żarnowski Wrocław 1984, s. 144; Zob. A. Bocheński, Między Niemcami a Rosją, Warszawa 1994.

67 A. Chojnowski, op. cit., s. 239.

68 Ibidem, s. 235. 


\section{Bibliografia}

Bączkowski W., Bocheński A., Łoś S., Problem polsko-ukraiński w ziemi czerwińskiej, Warszawa 1938. Bocheński A., Między Niemcami a Rosją, Wydawnictwo „Nałęcz”, Warszawa 1994.

Böhm T., Osadnictwo wojskowe na Kresach Wschodnich w II Rzeczypospolitej, „Dzieje Najnowsze” 1992, z. $1-2$.

Brożek A., Ręgorowicz Ludwik Walenty, „Polski Słownik Biograficzny”, t. XXXI, Polska Akademia Umiejętności, Wrocław-Warszawa-Kraków-Gdańsk-Łódź 1988-1989.

Chojnowski A., Koncepcje polityki narodowościowej rządów polskich w 1921-1931, Zakład Narodowy im. Ossolińskich, Wrocław 1979.

Czajkowski J., Dzieje osadnictwa historycznego na Podkarpaciu i jego odzwierciedlenie w grupach etnograficznych, [w:] Łemkowie w historii i kulturze Karpat, red. J. Czajkowski Editions Spotkania, Rzeszów 1992.

Dunin-Borkowski P., Punkt wyjścia w sprawie ukraińskiej w Małopolsce Wschodniej, „Droga” 1929, nr 6.

Fastnach F., Osadnictwo Ziemi Sanockiej w latach 1340-1650, Zakład Narodowy im. Ossolińskich, Wrocław 1962.

Giertych J., O programie polityki kresowej, Nakł. Tow. Wyd. „Patria” Spółdz. z Odp. Udz., Warszawa 1932.

Grabski S., Kresy i narodowości, „Lwowski Kurier Poranny”, Lwów 1930.

Horbal B., Działalność polityczna Łemków na Łemkowszczyźnie 1918-1921, Wydawnictwo Arboretum, Wrocław 1997.

Horoszkiewicz R., Szlachta zagrodowa na ziemiach wschodnich, Warszawa 1936. b.m.w.

Hrycak J., Historia Ukrainy 1772-1999. Narodziny nowoczesnego narodu, IEŚW, Lublin 2000.

Jędruszczak H., Jędruszczak T., Ostatnie lata Drugiej Rzeczypospolitej, 1935-1939, Książka i Wiedza, Warszawa 1970.

Kępa M., Kościół greckokatolicki w diecezji przemyskiej w II Rzeczypospolitej, Imponderabilia. Biuletyn Piłsudczykowski, Gdańsk 2014.

Kozik J., Między reakcją a rewolucją: studia $z$ dziejów ukraińskiego ruchu narodowego w latach 1948-1949, Kraków 1979.

Lewandowski J., Konflikt polsko-ukraiński na tle konfliktów narodowych w Europie środkowo-wschodniej w XIX i XX w., „Warszawskie Zeszyty Ukrainoznawcze” 1994, z. 2.

Lewickyj J., Grammatik der ruthenischen oder kleine russischen Sprache in Galizien, Przemyśl 1834.

Madajaczyk Cz., Dokumenty w sprawie polityki narodowościowej władz polskich na Kresach Wschodnich, „Dzieje Najnowsze” 1972, z. 1-2.

Majchrowski J.M., Silni-zwarci-gotowi. Myśl polityczna Obozu Zjednoczenia Narodowego, Wydawnictwo Naukowe PWN, Warszawa 1985.

Moklak J., Łemkowszczyzna w Drugiej Rzeczypospolitej. Zagadnienia polityczne i wyznaniowe, Towarzystwo Wydawnicze „Historia Iagellonica”, Kraków 1997.

Moklak J., Relacje między ukraińskim ruchem narodowym a moskalofilstwem w Galicji Wschodniej w latach 1866-1890, Wydawnictwo Uniwersytetu Jagiellońskiego, Kraków 1985.

Olszański T.A., Historia Ukrainy XX w., Oficyna Wydawnicza Volumen, Warszawa 1994.

Papierzyńska-Turek M., Sprawa ukraińska w II Rzeczypospolitej 1922-1926, Wydawnictwo Literackie, Kraków 1979.

Paruch W., Mniejszości narodowe myśli politycznej obozu piłsudczykowskiego (1935-1939), [w:] Paruch W., Polityka narodowościowa państw Europy środkowowschodniej, „Czas”, Lublin 1993.

Pijaj S., Florian Ziemiałkowski a „kwestia ukraińska”, [w:] Przez dwa stulecia, red. W. Frazik, Wydaw. Instytut Teologiczny Księży Misjonarzy, Kraków 1993.

Piotrkiewicz T., Kwestia ukrainska w Polsce w koncepcjach Piłsudczyzny 1926-1930, Wydawnictwo Uniwersytetu Warszawskiego, Warszawa 1981.

Potocki R., Polityka państwa polskiego wobec zagadnienia ukraińskiego w latach 1930-1939, IEŚW Lublin 2003. Prus-Faszczewski T., Małopolska Wschodnia a zagadnienia obronności państwa, Towarzystwo Rozwoju 
Ziem Wschodnich, Warszawa 1939.

Ręgorowicz L., Materiały do dziejów wychowania. Zagadnienia łemkowskie w Polsce, 1934 b.m.w.

Rzemianiuk F., Kościół katolicki obrządku bizantyjsko-słowiańskiego, Neounia, Lublin 1999.

Smoleński J., Łemkowie i Łemkowszczyzna, „Wierchy”, t. XIII, Kraków 1935.

Stawecki P., Następcy Komendanta. Wojsko a polityka wewnętrzna II Rzeczypospolitej w latach 1935-1939, Wydawnictwo MON, Warszawa 1969.

Stępień S., Nowa unia kościelna. Obrządek bizantyjsko-słowiański, [w:] Polska-Ukraina 1000 lat sąsiedztwa, t. II, Studia $z$ dziejów chrześcijaństwa. Na pograniczu kulturowym i etnicznym, red. S. Stępień, Południowo-Wschodni Inst. Naukowy, Przemyśl 1994.

Tomaszewski J., Stosunki narodowościowe w Drugiej Rzeczypospolitej, [w:] Polska Niepodległa 1918-1939, red. J. Żarnowski, Zakład Narodowy im. Ossolińskich, Wrocław 1984.

Torzecki R., Kwestia ukraińska w Polsce w latach 1923-1929, Wydawnictwo Literackie, Kraków 1989.

Torzecki R., Polacy i Ukraińcy. Sprawa Ukraińska w czasie II wojny światowej na terenie II Rzeczypospolitej, Wydawnictwo Naukowe PWN, Warszawa 1993.

Werschler I., Z dziejów obozu belwederskiego. Tadeusz Hołówko, życie i działalność, Wydawnictwo Naukowe PWN, Warszawa 1984.

Wielhorski W., Łemkowszczyzna, 1933 b.m.w.

\section{Ethnic policy of the Second Republic of Poland towards the Lemkos}

Keywords: ethnic policy, the Lemkos, the Second Republic of Poland, assimilation

\section{Summary}

Ethnic policy towards the "non-Polish" population, in particular considering the ethnic group of the Lemkos in the period of the Second Republic of Poland was characterised by two concepts of assimilation: ethnic and national. Undoubtedly, one figure who distinguished himself in the process of creating policy towards the Lemkos was W. Wielhorski, who effectuated clear and complete examination of the Lemkos issue in the Second Republic of Poland. Any operations undertaken by Polish authorities aimed at gaining loyalty of the Lemkos population as well as at conferring autonomy in order to maintain their ethnic or cultural distinctiveness. The twilight of the 1930s saw a change in the government's orientation towards the "non-Polish" population which was expressed in a military, nationalistic way of leading the ethnic policy. 